\title{
Technological Characterization and Stability of Ilex paraguariensis St. Hil. Aquifoliaceae (Maté) Spray-Dried Powder
}

\author{
Francini K.J. Yatsu, Greice S. Borghetti, and Valquiria L. Bassani \\ Postgraduate Program in Pharmaceutical Sciences, Faculty of Pharmacy, Federal University of Rio Grande do Sul, Porto Alegre, \\ Rio Grande do Sul, Brazil
}

\begin{abstract}
The present work was designed to produce an Ilex paraguariensis spray-dried powder (SDP), in semiindustrial scale, in order to characterize its technological and chemical properties as well as to evaluate the thermal stability and photostability of the main polyphenol constituents. The yield of the spray-drying process was satisfactory (67\%). The resulting SDP showed to be a material presenting spherical particles with a mean size of $19.6 \mu \mathrm{m}$, smooth surface, and good flow properties. The four polyphenol compounds previously reported for the species-neochlorogenic acid, chlorogenic acid, cryptochlorogenic acid, and rutin-were identified. Regarding the photostability test, the polyphenols present in the SDP proved to be stable against ultraviolet $\mathrm{C}$ radiation for 48 hours, independently of the packaging material. In the thermal stability test, the polyphenols were demonstrated to be hygroscopic and responsive to temperature $\left(40^{\circ} \mathrm{C}\right)$ under an atmosphere of high relative humidity (75\%) for 4 months, especially when the SDP was conditioned in permeable flasks. These findings demonstrate that heat and residual moisture content play an important role in the stability of the polyphenols and reinforce the relevance of conditioning SDP in humid tight packages under low temperatures.
\end{abstract}

KEY WORDS: $\bullet$ herbal dry extract $・$ Ilex paraguariensis $・$ maté $\bullet$ polyphenols $\bullet$ stability

\section{INTRODUCTION}

$\mathbf{I}^{\prime}$ LEX PARAGUARIENSIS (St. Hil., Family Aquifoliaceae) is a native plant from the subtropical region of South America, including southern Brazil, Uruguay, Paraguay, and Argentina. It is widely consumed as an infusion of roasted and dried leaves (chimarrão), green dried leaves brewed with cold water (tererê), or roasted leaves brewed with hot water (maté tea).

Aqueous extract solutions (ESs) of I. paraguariensis (decoction or infusion) contain different bioactive constituents, in particular methylxanthines, ${ }^{1,2}$ saponins, ${ }^{3-7}$ and phenolic compounds. ${ }^{8,9}$ Several in vitro studies have shown the important role of polyphenols on the antioxidant activity of I. paraguariensis. ${ }^{10-13}$ These studies suggest the potential use of I. paraguariensis aqueous extracts for the development of natural products with the aim of protecting biological systems against oxidative stress-mediated damages.

However, under the technological point of view, it is well known that aqueous extracts obtained from medicinal plants, in general, exhibit low stability. ${ }^{14}$ Their phenolic compounds, in particular, are extremely sensitive to oxida-

Manuscript received 1 March 2010. Revision accepted 29 May 2010.

Address correspondence to: Valquiria L. Bassani, Faculdade de Farmácia, Universidade Federal do Rio Grande do Sul, Av. Ipiranga 2752, CEP 90610-000, Porto Alegre, RS, Brazil, E-mail: valquiria@pq.cnpq.br tion and thermal degradation in aqueous media. ${ }^{15,16}$ Spraydrying has shown to be one of the most appropriate techniques of solvent elimination to overcome this problem. ${ }^{17}$ Our previous reports have demonstrated the feasibility of obtaining dried products, by the spray-drying technique, from aqueous extract solutions of I. paraguariensis. ${ }^{18-20}$ However, as far as we know, there are no references concerning the stability of polyphenols present in the corresponding dried products.

In this context, the present work was designed to produce, in semi-industrial scale, an I. paraguariensis spray-dried powder (SDP), to characterize its technological and chemical properties and to investigate the thermal and photostability of the main polyphenol constituents.

\section{MATERIALS AND METHODS}

\section{Chemicals}

Colloidal silicon dioxide (Aerosil ${ }^{\circledR}$ 200, Degussa, São Paulo, Brazil) was used as a drying excipient. Chlorogenic acid and rutin hydrate (Sigma-Aldrich, Steinheim, Germany) were used as external standards. Liquid chromatography (LC)-grade methanol (Tedia, Fairfield, OH, USA), acetic acid (Cromoline, São Paulo), and purified water (Milli-Q ${ }^{\circledR}$ system, Millipore, Bedford, MA, USA) were used for mobile phase preparation. 


\section{Plant material}

I. paraguariensis leaves and stems were collected in Ilópolis, Rio Grande do Sul State, in the south of Brazil. The specimen was identified and deposited (voucher number 142488) at the Herbarium of the Universidade Federal do Rio Grande do Sul, Porto Alegre, RS, Brazil. The traditional method for producing erva-mate was used; in brief, the raw material was stabilized by roasting, and afterward it was dried and ground.

\section{SDP preparation}

An aqueous ES was prepared by decoction of I. paraguariensis leaves at $96^{\circ} \mathrm{C}$ for 15 minutes, at a plant:solvent ratio of $1.5: 10$. The ES was cooled down to $40^{\circ} \mathrm{C}$ and filtered. Colloidal silicon dioxide was added to the ES at a 3:7 ratio (excipient:dry residue) and mixed for 30 minutes. The resulting dispersion was spray-dried using a Niro Production Minor atomizer (GEA, Copenhagen, Denmark) under the following operating conditions: $10,900 \mathrm{rpm}$ disk rotation rate, $177^{\circ} \mathrm{C}$ inlet air temperature, $99^{\circ} \mathrm{C}$ outlet air temperature, and $143 \mathrm{~mL} /$ minute feed flow.

\section{Technological characterization}

Yield and moisture content. The yield of the SDP was calculated as the difference between the theoretical weight of solid materials present in the sprayed ES and the weight of the powder obtained at the end of the drying process, taking into account the residual moisture content determined by the titrimetric method. ${ }^{21}$

Particle size. The mean particle size of the SDP was determined using a laser light scattering system (Malvern Instruments Ltd., Malvern, United Kingdom).

Bulk and tapped density (Hausner's Ratio and Carr's Index). The density parameters of the SDP were determined using $10.0 \mathrm{~g}$ of sample in a $50-\mathrm{mL}$ graduated cylinder mounted on a mechanical tapping device ${ }^{22}(\mathrm{~J}$. Engelsmann AG, Ludwigshafen, Germany). The bulk density was calculated as the ratio between the sample weight (in $\mathrm{g}$ ) and the initial volume (in $\mathrm{mL}$ ), and the tapped density was defined as the ratio between the sample weight (in g) and the final volume (in $\mathrm{mL}$ ). Carr's Index ${ }^{23}$ and Hausner's Ratio ${ }^{24}$ were calculated according to the following equations:

$$
\begin{aligned}
& \text { Carr's Index }=\frac{(\text { Tapped density }- \text { Bulk density })}{\text { Tapped density }} \times 100 \\
& \text { Hausner's Ratio }=\frac{\text { Tapped density }}{\text { Bulk density }}
\end{aligned}
$$

Angle of repose. The angle of repose $\mathrm{e}^{25}$ of the SDP was measured according to the following equation:

$$
\operatorname{Tg} \theta=h / r
$$

where $\operatorname{Tg} \theta$ is the tangent of the angle of repose, $h$ is the height, and $r$ is the radius.

\section{Scanning electron microscopy}

The photomicrographs of the SDP were taken using a Jeol (Tokyo, Japan) JSM 6060 microscope at a voltage of $10 \mathrm{kV}$. The samples were previously mounted on aluminum stubs using double-sided adhesive tape and vacuum-coated with a thin layer of gold.

\section{Polyphenol assay}

Chromatographic conditions. The LC analysis of the SDP was performed as described by Silva et al., ${ }^{26}$ using a Shimadzu (Kyoto, Japan) Prominence device coupled to a SPD-20A ultraviolet (UV)/visible detector. The stationary phase was a Shimadzu RP-18 column [CLC-ODS (M) $250 \times 4.6 \mathrm{~mm}$ i.d.; particle size, $5 \mu \mathrm{m}]$ guarded by a Waters (Milford, MA, USA) precolumn $(20 \times 3.9 \mathrm{~mm}$ i.d.; particle size, $10 \mu \mathrm{m})$. The mobile phase consisted of (A) acetic acid $2.0 \%$ (vol/vol) and (B) methanol:water (85:15, wt $/ \mathrm{wt})$. The gradient elution was 31\% B (0-10 minutes), 31-56\% B (1025 minutes), 56\% B (25-33 minutes), 56-77\% B (33-45 minutes), 77-56\% B (45-50 minutes), and 56-31\% B until 60 minutes. The flow rate was $0.7 \mathrm{~mL} /$ minute, and the injection volume was $20 \mu \mathrm{L}$. The detection wavelength was $340 \mathrm{~nm}$, and the analysis was carried out at room temperature.

Calibration curves. Chlorogenic acid and rutin were used as external standards. They were dissolved in methanol:water $(50: 50, \mathrm{vol} / \mathrm{vol})$ and diluted to obtain the concentrations of $2.0,4.5,6.0,8.0$, and $10.0 \mu \mathrm{g} / \mathrm{mL}$. These solutions were filtered through a membrane filter (pore size, $0.45 \mathrm{~mm}$; HVLP, Millipore). The linear equations were $y=67,255 x-13,006\left(r^{2}=0.9993\right)$ and $y=4,3584 x-$ $7,053.5\left(r^{2}=0.9991\right)$ for chlorogenic acid and rutin, respectively.

\section{Sample preparations}

The SDP (54.5 mg) was dispersed in $50.0 \mathrm{~mL}$ of water. From this colloidal dispersion, an aliquot of $2.0 \mathrm{~mL}$ was diluted to $10.0 \mathrm{~mL}$ with a mixture of methanol:water (50:50, $\mathrm{vol} / \mathrm{vol})$. The resulting solution was filtered through a membrane (pore size, $0.45 \mathrm{~mm}$; HVLP, Millipore) and analyzed by LC, taking into account the residual moisture content of the SDP. In the stability tests the moisture content was determined by the titrimetric method ${ }^{21}$ for the samples collected in each time. The content of neochlorogenic acid, chlorogenic acid, cryptochlorogenic acid, P4, P5, and P6 in the samples was calculated by the chlorogenic acid linear equation. The content of rutin was calculated by the corresponding linear equation.

\section{Photostability test}

The photostability test was carried out according to the method of the International Conference on Harmonisation. ${ }^{27}$ 

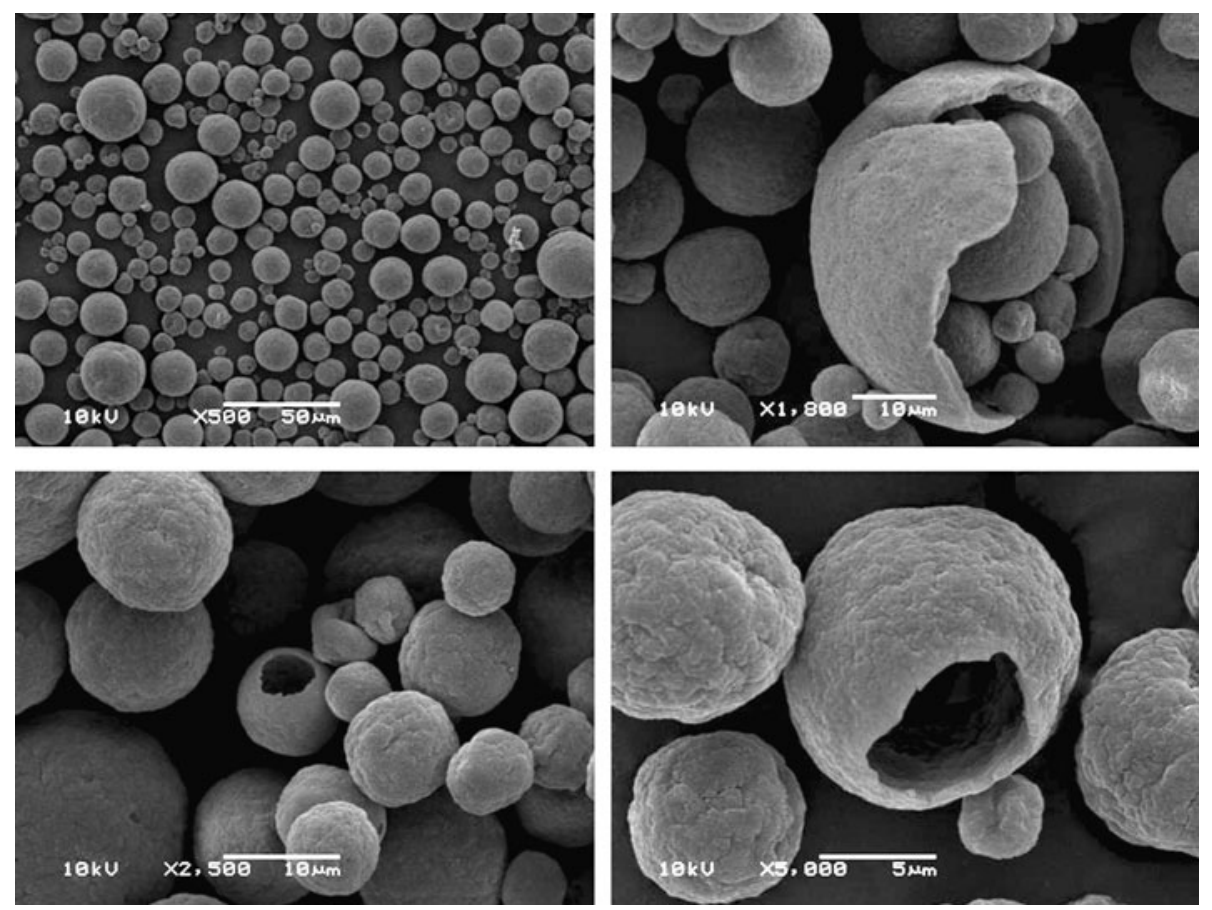

FIG. 1. Photomicrographs of I. paraguariensis spray-dried powder.
The SDP was exposed to UVC radiation (Light Express LE UV [CSR, Tokyo, Japan], $254 \mathrm{~nm}, 30 \mathrm{~W}$ ) for 48 hours under three different storage conditions: amber glass bottles, transparent glass bottles, or open dishes. The lamp was fixed to a chamber $(100 \times 16 \times 16 \mathrm{~cm})$ in a horizontal position, at a distance of approximately $10 \mathrm{~cm}$. The chamber was internally coated with mirrors in order to uniformly distribute the radiation. A sample wrapped in aluminum foil was used as a dark control to evaluate the influence of temperature into the chamber (approximately $27^{\circ} \mathrm{C}$ ) on the stability of the polyphenols. The polyphenol content in the samples was measured in triplicate at $0,12,24$, and 48 hours after irradiation, using the above-described LC method.

\section{Thermal stability test}

The thermal stability test was carried out at $40 \pm 2{ }^{\circ} \mathrm{C}$ and $75 \pm 5 \%$ relative humidity for 4 months to evaluate the stability of the polyphenols under accelerated conditions. SPD was conditioned in transparent glass bottles or

Table 1. Technological Parameters of Spray-Dried Powder OF I. PARAGUARIENSIS

\begin{tabular}{ll}
\hline Technological parameter & Value \\
\hline Moisture content & $6.64 \%$ \\
Yield & $67 \%$ \\
Bulk density & $0.75 \mathrm{~g} / \mathrm{mL}$ \\
Tapped density & $0.85 \mathrm{~g} / \mathrm{mL}$ \\
Hausner's Ratio & 1.13 \\
Carr's Index & $11.19 \%$ \\
Angle of repose & $27.78^{\circ}$ \\
Mean particle size & $19.6 \mu \mathrm{m}$ \\
\hline
\end{tabular}

poly(ethylene terephthalate) (PET) bottles. The polyphenol content in the samples was measured in triplicate at $0,1,2$, 3 , and 4 months after exposure in a climatic chamber (Nova Ética, São Paulo) using the above-described LC method. This condition was chosen to evaluate the effect of temperature and relative humidity on the stability of the polyphenols.

\section{Statistical analysis}

The results were analyzed either by Student's $t$ test or by analysis of variance followed by Tukey's test for significance at $P$ values $<.05$.

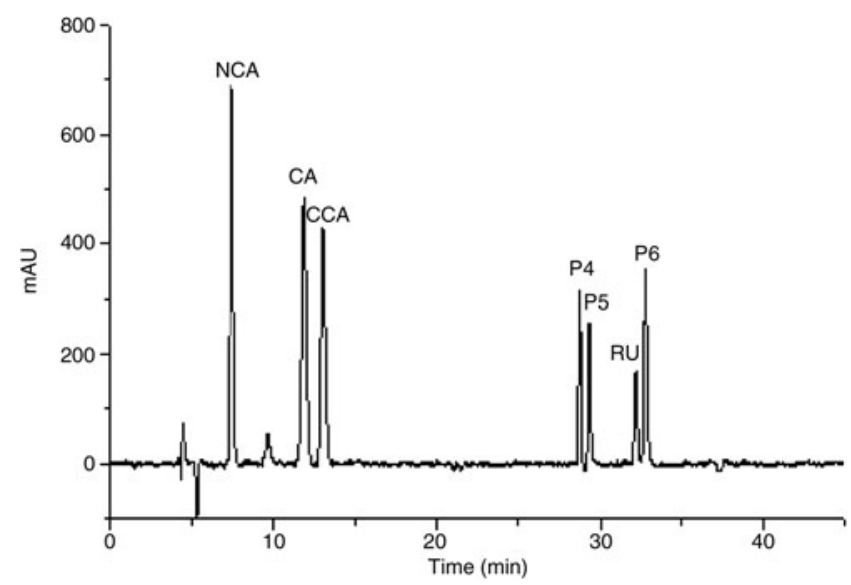

FIG. 2. Chromatographic profile of polyphenols present in $I$. paraguariensis spray-dried powder. CA, chlorogenic acid; CCA, cryptochlorogenic acid; NCA, neochlorogenic acid; P4, P5, and P6, isomeric dicaffeoyl esters of quinic acid; RU, rutin. mAU, milliabsorbance units. 

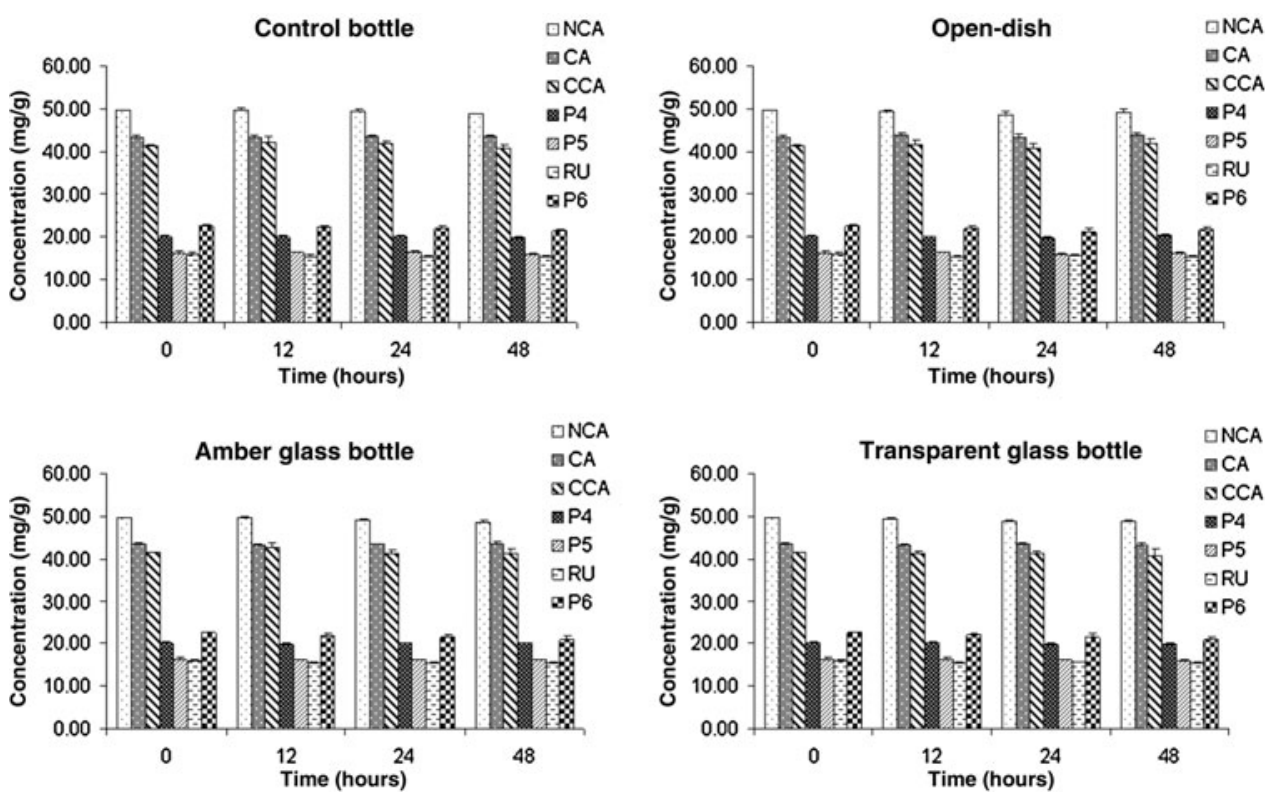

FIG. 3. Polyphenol content of $I$. paraguariensis spray-dried powder stored under different conditions during 48 hours of exposure to ultraviolet $\mathrm{C}$ radiation $(n=3)$

\section{RESULTS}

SPD technological characterization and polyphenol assay

The spray-drying process of the aqueous ES of I. paraguariensis leaves yielded a fine yellow powder. The technological characteristics of the SDP are presented in Figure 1 and Table 1. The LC profile of polyphenols present in SDP is shown in Figure 2.

\section{Photostability test}

After 48 hours of exposure to UVC radiation, the original macroscopic characteristics of SDP were not altered, and no change was detected in the LC profile (data not shown). The polyphenol content of the SDP was not significantly $(P<.05)$ altered when it was stored in open dishes, amber glass bottles, or transparent glass bottles (Fig. 3). The residual moisture content of the SDP samples presented no significant difference $(P<.05)$ over the photostability test (data not shown).

\section{Thermal stability test}

There was no change in the retention time of the polyphenols, and no new peak appeared in the chromatogram for the thermal stability test (data not shown).

The color of the SDP samples conditioned in PET bottles became brown. In these samples, the residual moisture content of the SDP was significantly $(P<.05)$ increased from $6.64 \%$ (initial) to $13.96 \%$ (after 4 months). However, when the SDP samples were conditioned in transparent glass bottles, their residual moisture content and color were not altered (data not shown).

Simultaneously, after 4 months, a significant $(P<.05)$ decrease was observed in the total polyphenol content of the SDP samples conditioned in both transparent glass bottles (from $209.52 \mathrm{mg} / \mathrm{g}$ to $141.98 \mathrm{mg} / \mathrm{g}$ ) and PET bottles (from $209.52 \mathrm{mg} / \mathrm{g}$ to $132.03 \mathrm{mg} / \mathrm{g}$ ), especially in the latter (Fig. 4).

However, an anomalous behavior was observed for cryptochlorogenic acid (Fig. 5). Until the third month, there was a significant $(P<.05)$ increase in its concentration, which was more pronounced for the SDP samples conditioned in PET bottles (133.9\%) than for those conditioned in transparent glass bottles (114.2\%). In the fourth month, the cryptochlorogenic acid concentration decreased to a value (91.9\% and $79.6 \%$ for PET bottles and transparent glass bottles, respectively) significantly $(P<.05)$ lower than the initial result. The degradation kinetics of the polyphenol compounds present in the SDP could not be determined because their degradation was not greater than $50 \%$.

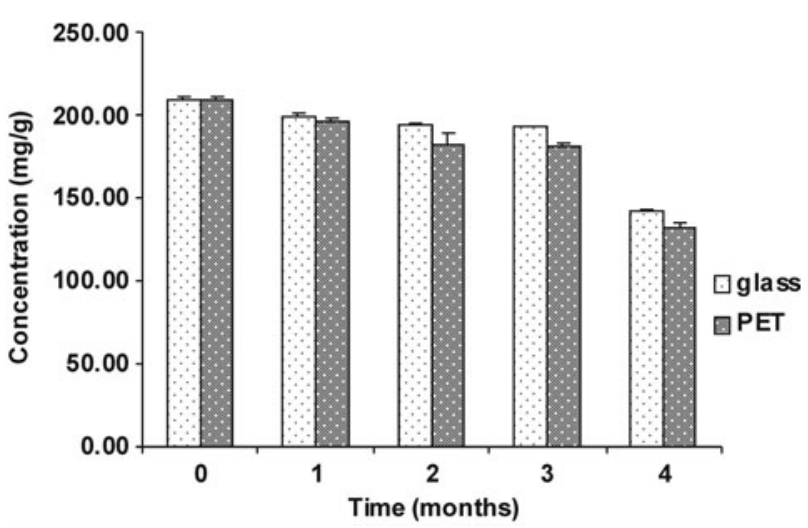

FIG. 4. Total polyphenol content of I. paraguariensis spray-dried powder under accelerated conditions $\left(40^{\circ} \mathrm{C}, 7 \%\right.$ relative humidity, 4 months) $(n=3)$. Glass, conditioned in transparent glass bottles; PET, conditioned in poly(ethylene terephthalate) bottles. 

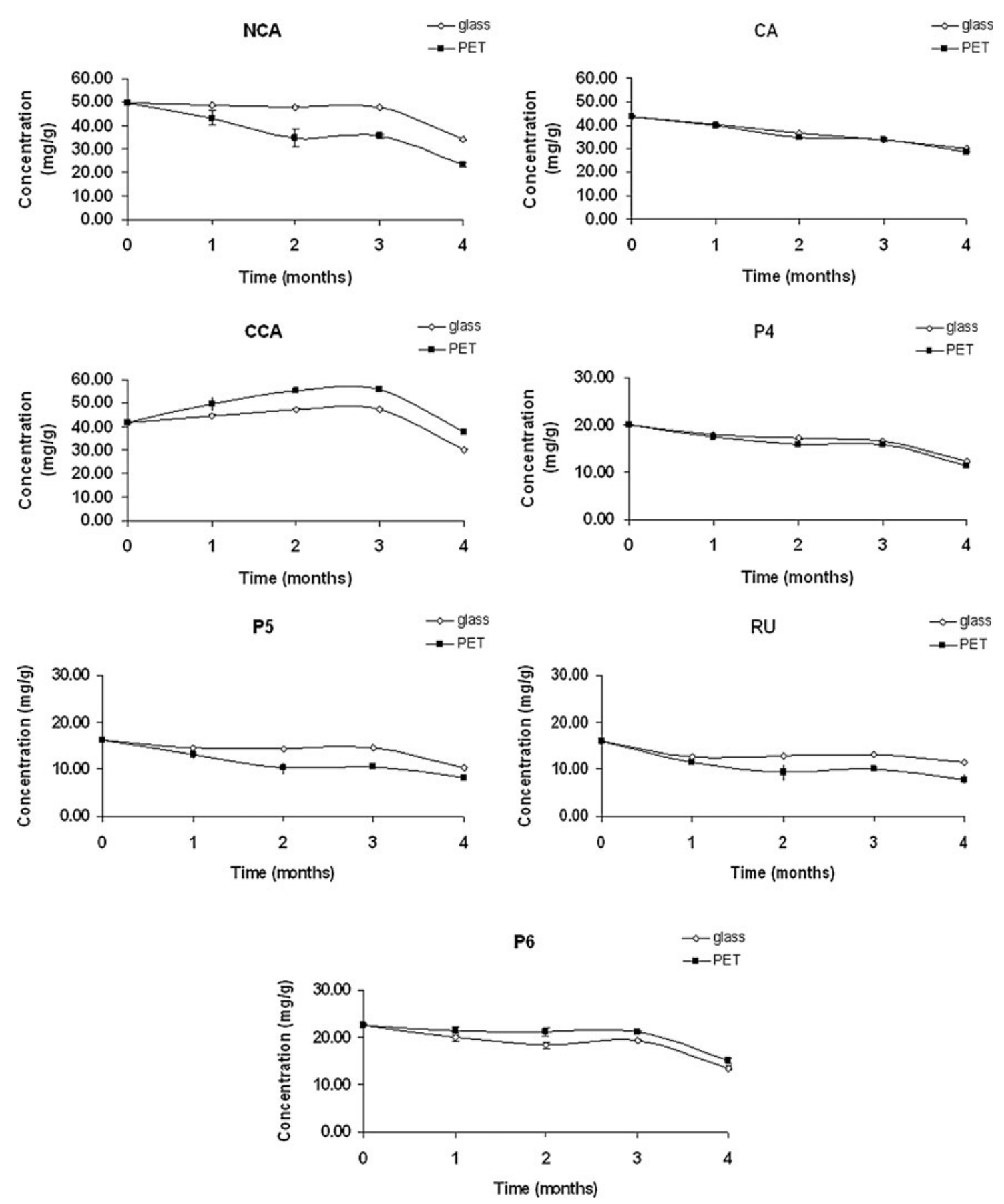

FIG. 5. Polyphenol content of $I$. paraguariensis spray-dried powder under accelerated conditions $\left(40^{\circ} \mathrm{C}, 75 \%\right.$ relative humidity, 4 months $)(n=3)$.

\section{DISCUSSION}

SPD technological characterization and polyphenol assay

Despite the hydrophilic characteristic of the herbal constituents extracted by hot water and the limitations for obtaining the corresponding dry powder, the yield of the spray-drying process can be considered satisfactory (67\%). This yield is related, partially at least, to the presence of colloidal silicon dioxide as the excipient, which presents remarkable adsorbent and nonadherent properties. Additionally, it increases droplet density, thus promoting an improvement in powder recovery. ${ }^{28,29}$

Carr's Index and Hausner's Ratio are frequently used as an indication of the flowability of a powder. A Carr's Index value below 15 and a Hausner's Ratio value lower than 1.25 indicate a good ability to flow. As an indirect measurement of flow, the angle of repose was also determined. Values of 
angle of repose lower than $30^{\circ}$ characterize free-flowing materials. The results obtained indicate a material with particular stable accommodation and good flow properties. Moreover, the SDP particles showed to be spherical with a smooth surface, which probably contributed to its low agglomerating tendency.

The residual moisture content of the SDP $(6.64 \%)$ was above the maximum limit (4.0\%) set for herbal dry extracts by the official pharmaceutical code.$^{30}$ However, this value is below the maximum limit (7.0\%) accepted for herbal powders with non-hermetic packaging. ${ }^{31}$

The peaks corresponding to the four polyphenol compounds previously reported for the species by Silva et al. ${ }^{26}$ were identified: neochlorogenic acid, retention time 7.0 minutes; chlorogenic acid, retention time 10.8 minutes; cryptochlorogenic acid, retention time 11.6 minutes; and rutin, retention time 30.4 minutes. The non-identified peaks P4 (at 27.0 minutes), P5 (at 27.7 minutes), and P6 (at 30.8 minutes), probably corresponding to isomeric dicaffeoyl esters of quinic acid (i.e., 3,4-O-dicaffeoyl, 4,5-O-dicaffeoyl, 3,5-O-dicaffeoyl, or 1,5-O-dicaffeoyl esters), could also be observed.

\section{Photostability test}

The polyphenols present in the SDP proved to be stable against UVC radiation, independently of the packaging material (amber glass bottles, transparent glass bottles, or open dishes). One hypothesis for this observation is the protective effect provided by the use of colloidal silicon dioxide as the excipient. The photoprotection mechanism of colloidal silicon dioxide is most likely similar to that reported for titanium dioxide and zinc oxide because of their physical similarity. These inorganic agents are able to reflect and scatter UV and visible radiation from a film of inert metal particles that forms an opaque barrier. ${ }^{32}$ However, we are not able to evaluate if this effect takes place in the SDP because it is a complex matrix.

\section{Thermal stability test}

Two different packaging materials-transparent glass bottles (impermeable) and PET bottles (semipermeable)were chosen to evaluate the effect of temperature $\left(40^{\circ} \mathrm{C}\right)$ on the stability of the polyphenols when the SDP was exposed to an atmosphere of high relative humidity (75\%) for 4 months. The total polyphenol content was evaluated in this study because the biological effects of herbal drugs and their preparations very often occur because of the whole phytocomplex rather than of a single constituent.

The polyphenols appeared to be less affected by heat when the SDP was conditioned in impermeable flasks than when it was conditioned in semipermeable flasks. The SDP samples conditioned in semipermeable flasks were demonstrated to be hygroscopic, suggesting the influence of the high residual moisture content of these samples on the stability of the polyphenols. In this case, the presence of water facilitates the occurrence of the enzymatic reactions, which are accelerated by the effect of temperature. ${ }^{33}$ Peroxidase and polyphenol oxidase have been considered the enzymes responsible for quality deterioration and browning in maté tea leaves. ${ }^{33}$ Therefore, considering that peroxidase is a very thermostable enzyme, whose activity can be regenerated after thermal treatment, ${ }^{34-37}$ the degradation of polyphenol compounds in the present study may be associated, at least in part, with the residual activity of this enzyme. It should be noted that the degradation process of polyphenols also depends on other factors, such as the presence of oxidizing substances.

In the same way, the most pronounced increase of the cryptochlorogenic acid concentration observed for the SDP samples conditioned in semipermeable flasks, in the first 3 months of the thermal stability test, can also be attributed to the high residual moisture content of these samples. One hypothesis to explain this phenomenon, considering the presence of cryptochlorogenic acid isomers (chlorogenic acid and neochlorogenic acid) in the SDP, is the interconversion of polyphenol compounds under accelerated conditions.

In conclusion, an I. paraguariensis SDP was produced in semi-industrial scale with satisfactory technological properties and high content of polyphenols, which makes it a promising candidate for the development of derivative products with the aim to protect biological systems against oxidative stress-mediated damages. The findings also reinforce the relevance of conditioning SDP in humidity-tight packages under low temperatures in order to maintain the stability of the polyphenols.

\section{ACKNOWLEDGMENTS}

The authors are grateful to the Coordenação de Aperfeiçoamento de Pessoal de Nível Superior and to the Conselho Nacional de Desenvolvimento Científico e Tecnológico for the financial support and the scholarships.

\section{AUTHOR DISCLOSURE STATEMENT}

We declare that there are no competing financial interests for any author of this article.

\section{REFERENCES}

1. Filip R, Iglesias DIA, Rondina RVD, Coussio JD: Análisis de las hojas y tallos de Ilex argentina Lillo. I. Xantinas. Acta Farm Bonaerense 1983;2:87-90.

2. Reginatto FH, Athayde ML, Gosmann G, Schenkel EP: Methylxanthines accumulation in Ilex species-caffeine and theobromine in erva-mate (Ilex paraguariensis) and other Ilex species. J Braz Chem Soc 1999;10:443-446.

3. Gosmann G, Schenkel EP, Seligmann O: A new saponin from mate, Ilex paraguariensis. J Nat Prod 1989;52:1367-1370.

4. Gosmann G, Guillaume D, Taketa ATC, Schenkel EP: Triterpenoid saponins from Ilex paraguariensis. J Nat Prod 1995; 58:438-441.

5. Kraemer KH, Taketa ATC, Schenkel EP, Gosmann G, Guillaume D: Matesaponin 5, a highly polar saponin from Ilex paraguariensis. Phytochemistry 1996;42:1119-1122. 
6. Schenkel EP, Montanha JA, Gosmann G: Triterpene saponins from maté, Ilex paraguariensis. Adv Exp Med Biol 1996;405:4756.

7. Martinet A, Ndjoko K, Terreaux C, Marston A, Hostettmann K, Schutz Y: NMR and LC-MS characterization of two minor saponins from Ilex paraguariensis. Phytochem Anal 2001;12:48-52.

8. Ricco RA, Wagner ML, Gurni AA: Estudio comparativo de flavonoides en seis especies austrosudamericanas del género Ilex. Acta Farm Bonaerense 1991;10:29-35.

9. Filip R, López P, Giberti G, Coussio J, Ferraro G: Phenolic compounds in seven South American Ilex species. Fitoterapia 2001;72:774-778.

10. Younes M, Siegers CP: Inhibitory action of some flavonoids on enhanced spontaneous lipid peroxidation following glutathione depletion. Planta Med 1981;43:240-244.

11. Larson RA: The antioxidants of higher plants. Phytochemistry 1988;27:969-978.

12. Filip R, Lotito SB, Ferraro G, Fraga CG: Antioxidant activity of Ilex paraguariensis and related species. Nutr Res 2000;20:14371446.

13. Chandra SE, Mejia GE: Polyphenolic compounds, antioxidant capacity, and quinone reductase activity of an aqueous extract of Ardisia compressa in comparison to mate (Ilex paraguariensis) and green (Camellia sinensis) teas. J Agric Food Chem 2004; 52:3583-3589.

14. Oliveira WP, Bott RF, Souza CRF: Manufacture of standardized dried extracts from medicinal Brazilian plants. Dry Technol 2006;24:523-533.

15. Makris DP, Rossiter JT: Heat-induced, metal-catalyzed oxidative degradation of quercetin and rutin (quercetin 3-O-rhamnosylglucoside) in aqueous model systems. J Agric Food Chem 2000;48:3830-3838.

16. Buchner N, Krumbein A, Rohn S, Kroh LW: Effect of thermal processing on the flavonols rutin and quercetin. Rapid Commun Mass Spectrom 2006;20:3229-3235.

17. Masters K: Applications of spray drying. In: Spray-Drying, 4th ed. John Wiley \& Sons, New York, 1991, pp. 491-537.

18. Campos AM: Desenvolvimento de extratos secos nebulizados de Ilex paraguariensis A. St. Hil., Aquifoliaceae (Erva-mate) [Ph.D. Thesis]. Universidade Federal do Rio Grande do Sul, Porto Alegre, Brazil, 1996.

19. Gnoatto SCB: Metodologias analíticas para quantificação de marcadores químicos em preparações de Ilex paraguariensis (A. St. Hil.) e desenvolvimento de extrato seco por nebulização [Ph.D. Thesis]. Universidade Federal do Rio Grande do Sul, Porto Alegre, Brazil, 2002.

20. Silva FA: Avaliação tecnológica e atividade antioxidante de produtos secos por spray-drying de Ilex paraguariensis A. St. Hil._Aquifoliaceae (Erva-mate) [Ph.D. Thesis]. Universidade Federal do Rio Grande do Sul, Porto Alegre, Brazil, 2007.
21. USP United States Pharmacopoeia, 31st ed. U.S. Pharmacopoeia Convention, Rockville, MD, 2007.

22. Guyot JC, Arnaud P, Becourt P, Cassiere JP, Chulia D, Duchêne D, Ferrand D, Gouaihardou J, Langlois C, Lequien G, Malfroid F, Pourcelot Y, Renoux R, Segot S, Toure P: Commentaires relatifs aux méthodes générales d'analyse des formes orales solides récemment introduites dans les pharmacopées française et européenne. Rapport d'une commission SFSTP. STP Pharma Prat 1995;5:482-494.

23. Carr RL: Evaluating flow properties of solids. Chem Eng 1965;72:163-168.

24. Hausner HH: Friction conditions in a mass of metal powder. Int $J$ Powder Metall 1967;3:7-13.

25. Pathirana MGM, Gupta BK: Determination of the angle of repose by shadow tracing method. Can J Pharm Sci 1976;11:30-32.

26. Silva FA, Pavei C, Ortega GG, Lima EM, Diniz DGA, Moreira JCF, Bassani VL: Validation of a LC method for polyphenol assay in extractive solutions from Ilex paraguariensis (Mate). J Liquid Chromatogr Relat Technol 2007;30:3119-3131.

27. International Conference on Harmonisation. QIB Stability Testing: Photostability Testing of New Drug Substances and Products. ICH, Geneva, Switzerland, 2005.

28. Walton DE, Mumford CJ: Spray dried products: characterization of particle morphology. Trans I Chem 1999;77:21-38.

29. Martins AG, Guterres SS, González OG: Anti-ulcer activity of spray-dried powders prepared from leaf extracts of Maytenus ilicifolia Martius ex Reiss. Acta Farm Bonaerense 2003;22:3944.

30. Brazilian Pharmacopoeia, 4th ed. Atheneu, São Paulo, 2001.

31. List PH, Schmidt PC: Phytopharmaceutical Technology. CRC Press, Boca Raton, FL, 1989, p. 374.

32. Lautenschlager SMD, Wulf HC, Pittelkow M: Photoprotection. Lancet 2007;370:528-537.

33. Baertschi SW, Reynolds DW: Stress testing: a predictive tool. In: Pharmaceutical Stress Testing: Predicting Drug Degradation (Baertschi SW, ed.). Taylor and Francis, London, 2005, pp. 1344.

34. Panek AD: Dosagem da peroxidase nas folhas de mate. Bol Inst Quim Agric 1955;39:7-12.

35. Ceni GC, Baldissera EM, Antunes OAC, Oliveira JV, Dariva C, Oliveira D: Oxidases from mate tea leaves (Ilex paraguariensis): extraction optimization and stability at low and high temperatures. Bioprocess Biosyst Eng 2008;31:541-550.

36. Fatibello-Filho O, Vieira IC: Uso analítico de tecidos e de extratos brutos vegetais como fonte enzimática. Quim Nova 2002;25:455-464.

37. Terefe NS, Yang YH, Knoerzer K, Buckow R, Versteeg C: High pressure and thermal inactivation kinetics of polyphenol oxidase and peroxidase in strawberry puree. Innov Food Sci Emerg 2010;11:52-60. 